\title{
Onshore advection of warm water, larval invertebrate settlement, and relaxation of upwelling off central Chile
}

\author{
Diego A. Narváez ${ }^{1,3}$, Sergio A. Navarrete ${ }^{1, *}$, John Largier $^{2}$, Cristian A. $\operatorname{Vargas}^{1,4}$ \\ ${ }^{1}$ Estación Costera de Investigaciones Marinas \& Center for Advanced Studies in Ecology and Biodiversity, \\ Pontificia Universidad Católica de Chile, Casilla 114-D, Santiago, Chile \\ ${ }^{2}$ Bodega Marine Laboratory, University of California Davis, PO Box 247, Bodega Bay, California 94923, USA
}

${ }^{3}$ Present address: Center for Coastal Physical Oceanography, Department of Ocean, Earth, and Atmospheric Sciences, Old Dominion University, Crittenton Hall, 768 West 52nd Street, Norfolk, Virginia 23529, USA

${ }^{4}$ Present address: Aquatic System Unit, Environmental Sciences Center EULA - CHILE, Universidad de Concepción, Casilla 160-c, Concepción, Chile

\begin{abstract}
Observations from several places around the world suggest that periods of relaxation of winds tha drive upwelling favor the onshore transport of larvae entrained in shoreward movement of warm surface waters. However, the generality of this process has not yet been appropriately evaluated. We examined the frequency, intensity, spatial extent, and inter-annual variability of sea surface temperature fluctuations associated with the relaxation of equator-ward winds and their influence on invertebrate settlement in central Chile $\left(33^{\circ} 30^{\prime} \mathrm{S}, 71^{\circ} 40^{\prime} \mathrm{W}\right)$. Our results showed that there were marked differences in the intensity and structure of temperature increases following the relaxation of upwelling favorable winds. While most temperature increases were small $\left(0.5\right.$ to $\left.1^{\circ} \mathrm{C}\right)$ and preserved the stratification of the water column, large 'warming events' $\left(>3^{\circ} \mathrm{C}\right.$ ) led to a breakdown of stratification for periods of 3 to $9 \mathrm{~d}$ at least twice during each spring-summer season. These large warming events occurred in association with downwelling-favorable (northerly) winds, and their formation might have required certain conditions in terms of mesoscale eddy features and local topography. Settlement of invertebrates occurred during these events as well at other times, and was not quantitatively correlated with relaxation or downwelling conditions. However, during specific large warming events, we observed significant synchrony in the settlement of several marine invertebrate taxa (e.g. decapods, gastropods, polychaetes, mussels, and sea urchins). Thus, at this site in central Chile and during our period of study, relaxation events did not dominate settlement, and it appeared that the upwelling-relaxation model did not adequately represent the larval transport mechanism for any taxa examined. However, large warming events (which produced synchrony in the settlement of several different taxa) could be important in that they may result in uniform settlement along the shore and deliver larvae from distant origins, increasing long-distance demographic and genetic connectivity. Thus, these infrequent events are likely to be a critical factor in settlement distribution along the shore.
\end{abstract}

KEY WORDS: Large warming events · Onshore advection · Daily settlement · Upwelling · Downwelling $\cdot$ Relaxation $\cdot$ Larval invertebrates $\cdot$ Central Chile

Resale or republication not permitted without written consent of the publisher

\section{INTRODUCTION}

Cross-shelf wind-driven circulation is of special interest over the inner shelf because of the predominant role this process plays in transport and distribution of heat, salt, sediments, nutrients, and biological particles
(Austin \& Lentz 2002). Since most benthic species have pelagic larval stages, which largely depend on external transport mechanisms to return to shore and complete their life cycle (e.g. Thorson 1950, Roughgarden et al. 1988), a general understanding of these physical processes and variability along the shore is critical to 
model ecosystem and population dynamics from ecological, conservation, and management points of view (Ogden 1997, Lipcius et al. 2005). In particular, considerable efforts have been dedicated to determining the conditions that favor wind-driven upwelling and relaxation. Observations suggest that as wind forcing relaxes after a coastal upwelling event, warmer offshore waters move shoreward and/or alongshore currents reverse over the shelf. These flows can transport high concentrations of larvae, and significant settlement events have been observed associated with these relaxation flows (Farrel et al. 1991, Roughgarden et al. 1991, Wing et al. 1995a,b). Therefore, it is now generally expected that periods of relaxation (sometimes accompanied by downwelling-favorable winds) favor the transport of larvae entrained in onshore moving warm waters (Shanks et al. 2000, Garland et al. 2002). However, direct support for upwelling-relaxation larval transport model comes from only a handful of studies conducted at a few places around the world, notably concentrated in the USA. Moreover, while there is now considerable information about the oceanographic and topographic conditions that modulate the intensity of upwelling (e.g. Huyer 1983, Largier et al. 1993, Smith 1995, Figueroa \& Moffat 2000), fewer studies have examined in detail the dynamics and spatial extent of relaxation events (e.g. Send et al. 1987, Austin \& Lentz 2002, Shanks \& Brink 2005).

Like other eastern boundary systems, coastal upwelling forced by equator-ward winds, mainly during austral spring and summer months, is a dominant oceanographic feature in the Humboldt Current System of northern and central Chile $\left(18\right.$ to $40^{\circ} \mathrm{S}$ ) (Strub et al. 1998). Along this coast, a well-defined seasonality in climatic-hydrographic conditions (Cáceres \& Arcos 1991, Strub et al. 1998, Narváez et al. 2004) and phytoplankton biomass and productivity (Thomas 1999, Wieters et al. 2003) characterizes the region between 30 and $40^{\circ} \mathrm{S}$. Some studies have described the dynamics and spatial variation in the intensity of upwelling events along this region (e.g. Figueroa \& Moffat 2000, Sobarzo \& Djurfeldt 2004), but there are few direct observations that show variation in onshore advection of warm waters during relaxation of upwellingfavorable winds or when winds reverse direction. It is unclear, for instance, whether wind relaxation is sufficient to bring warm waters all the way back to the shore, or whether downwelling winds are necessary to force waters onshore. Further, the relative importance of local heating and advection in the increase of surface water temperature is unclear.

The hypothesis that larvae may be transported onshore as upwelling relaxes, or when alongshore currents reverse direction and come closer to shore, has not been evaluated in this region of the world.
Through the analysis of physical data and settlement time series, a recent study suggested the importance of tidal bores to the transportation of larvae of intertidal invertebrates to the rocky shore of central Chile (Vargas et al. 2004). Yet, the influence of events of upwelling-relaxation was not directly investigated. Although coupled studies of larval abundance and circulation are the most direct way to improve our knowledge on the oceanographic processes that influence invertebrate larval transport, one alternative is the use of settlement time-series data, through which we can infer the plausible physical mechanisms involved in the supply of larvae to the intertidal zone (e.g. Shanks 1986, Farrell et al. 1991, Roughgarden et al. 1991, Wing et al. 1995a,b, Vargas et al. 2004, Ladah et al. 2005). Settlement data have some limitations when inferring larval transport processes (Pineda 1999), especially because of differences in time integration between settlement and the physical transport process, and also due to temporal variation in the availability ('larval supply') and behavior of competent larvae. However, settlement data makes it easier to interpret the relevance of the process for benthic populations. The use of settlement time series to infer oceanographic transport processes also assumes that competent larvae are indeed present in the water column, and not in the benthic habitat-an assumption that is quite reasonable and generally made for invertebrate species with small, obligate larval stages.

Our study was conducted off Las Cruces (central Chile), a location which lies between 2 important upwelling centers: Punta Curaumilla to the north, and Punta Toro to the south (Strub et al. 1998, Wieters et al. 2003) (Fig. 1). It has been shown that slightly warmer waters tend to be retained in front of Las Cruces, within the Cartagena Bay, entrained by the cold waters upwelled downstream at Punta Toro (Wieters et al. 2003, Narváez et al. 2004). These cold waters are typically driven into Las Cruces area toward the end of an upwelling event, 1 to $2 \mathrm{~d}$ after the onset of upwelling favorable winds (Narváez et al. 2004). Therefore, it has been suggested that the area of Las Cruces is located in an upwelling shadow (sensu Graham \& Largier 1997). Although the ecology of intertidal communities is relatively well known in this area (see Castilla \& Paine 1987, Fernández et al. 2000), our knowledge about larval transport mechanisms is preliminary. Important onshore settlement of mussels, decapods and gastropods, as well as peaks in chlorophyll concentration, occur when conditions are favorable for the occurrence of tidal bores (Vargas et al. 2004). In their study, Vargas et al. (2004) described the general hydrographic conditions that favor the occurrence of tidal bores and how these conditions (e.g. strong stratification of the water column) are modulated by winds, 
tidal phase, and daily warming, but not by the lunar phase as seen on the coast of southern California (Pineda 1991, 1995). In our study we attempted to first characterize the frequency, intensity, and inter-annual variability of relaxation of upwelling-favorable winds, and then to assess their effects on the settlement of invertebrates.

\section{MATERIALS AND METHODS}

Physical data. In our study, we described 2 types of relaxation events and characterized the differences between them. With this aim, we examined sea surface temperature, local winds, upwelling indices, and currents from June 2001 to October 2002. We also analyzed water column temperature and upwelling indices for 2 periods, from October 1999 to February
2000 (spring-summer 1999/2000), and from January to March 2002 (summer 2002).

Long-term measurements of daily sea temperature at Las Cruces were obtained from a series of loggers with $\pm 0.3^{\circ} \mathrm{C}$ accuracy (Stow Away Tidbits, Onset Computers) suspended from 2 buoyant lines moored approximately $150 \mathrm{~m}$ (i.e. coastal mooring) and $10 \mathrm{~km}$ (i.e. oceanic mooring) from the shore, and at $20 \mathrm{~m}$ and $100 \mathrm{~m}$ bottom depths, respectively (Fig. 1). Loggers were suspended at $3,7,11,14,17$ and $20 \mathrm{~m}$ from the surface at the coastal mooring, and at 11, 15, 17, 25 and $90 \mathrm{~m}$ from the surface at the oceanic mooring. Due to loss of instruments, the oceanic mooring recorded only from January to April 2002, whereas temperature data for the coastal mooring were only obtained at 7,11 , $17 \mathrm{~m}$ for spring-summer 1999/2000 and 3, 7, 14, and $20 \mathrm{~m}$ depth for summer 2002. In addition to these moorings, temperature loggers were mounted subtidally
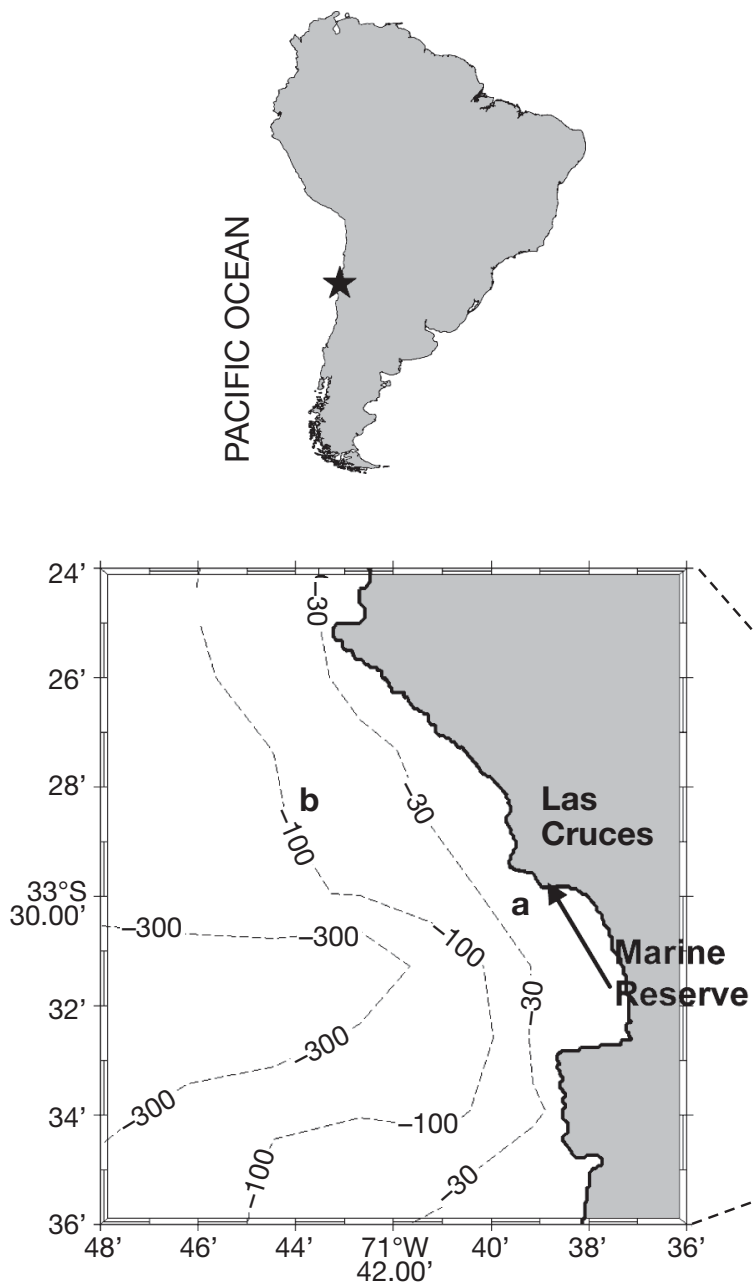

Fig. 1. $\star$ : Study area in central Chile; O: rocky subtidal temperature loggers, letters (left panel) represent the coastal (a) and oceanic (b) moorings off Las Cruces

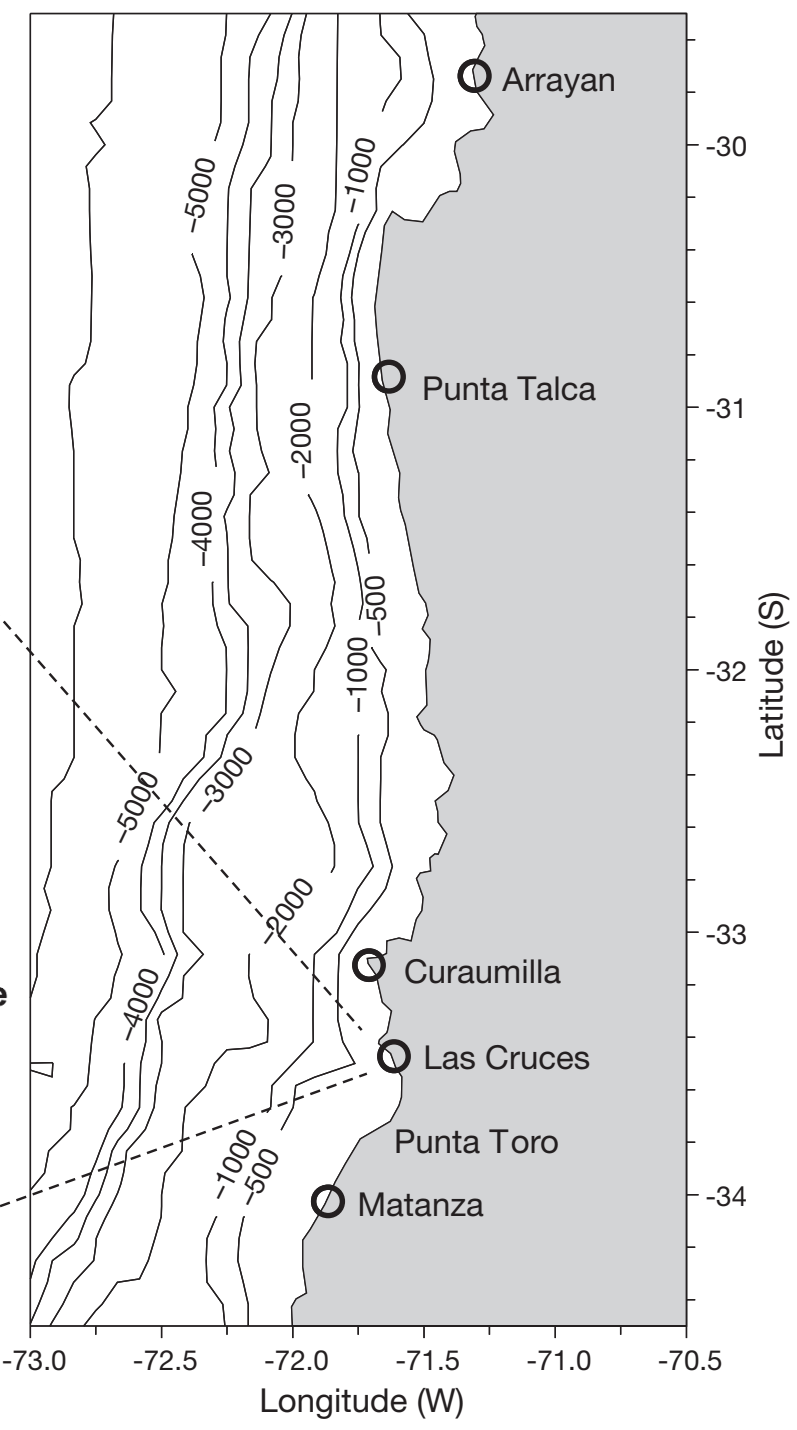


and directly on the rock surface at 1 to $2 \mathrm{~m}$ below the lowest low tide mark at 5 sites along the coast of central Chile between 30 and $34^{\circ} \mathrm{S}$ (Fig. 1). This allowed study of the variation in surface temperature over a larger spatial scale (up to $500 \mathrm{~km}$ ). We also analyzed Advanced Very High Resolution Radar (AVHRR) satellite images (resolution $1.1 \mathrm{~km}^{2}$ ), which were selected to cover specific events (see 'Results').

Current velocity data were obtained at the coastal mooring with a Sensordata 6000 current meter deployed at $12 \mathrm{~m}$ depth, and recording every hour. Local wind direction and speed were recorded every $20 \mathrm{~min}$ using a Campbell Meteorological Station located at the Estación Costera de Investigaciones Marinas (ECIM) in Las Cruces. In addition, to get an indication of when upwelling or downwelling events occurred over a larger spatial scale, we used daily upwelling indices (Offshore Ekman Transport: OET) at $33^{\circ} \mathrm{S}, 74^{\circ} \mathrm{W}$ provided by Pacific Fisheries Environmental Laboratory (PFEL; indices available from http://las.pfeg.noaa.gov).

Since temperature increases of the surface layer can be produced not only by advection of warm waters but also by solar radiation, we evaluated the effect of the net surface heat flux $(Q)$ on water column temperature in the study area (see Appendix 1).

Invertebrate settlement and larval biology. Daily settlement was measured between October 1999 and February 2000 at a rocky bench within the Marine Reserve of Las Cruces (Fig. 1). Settlement rates were quantified on 5 collectors made of $7 \mathrm{~cm}$ diameter plastic scrub pads (Tuffy) which were installed in the mid-intertidal zone and replaced daily (Navarrete et al. 2002). Collectors were scrubbed and washed in fresh water, and individual larvae were identified and counted under a dissecting microscope. Because of the lack of taxonomic descriptions of early stages, we were not able to separate species during the course of the settlement study (1999 to 2000) and, therefore, we pooled settlers within clearly distinctive taxa (readily identifiable categories). Subsequent studies (S. A. Navarrete unpubl. data) allowed us to identify which were the main species composing these taxa, but not the species in individual settlement pulses. The main taxa settling in the collectors were mussels (mostly Perumytilus purpuratus, and secondarily Semimytilus algosus), gastropods (mostly Austrolittorina araucana, secondarily Tricolia umbilicata), decapods (mostly Acanthocylcus gayi, secondarily Taliepus dentatus and Pilumnoides perlatus), polychaetes (mostly 1 species of Nereis), barnacles (cyprids of the chathamloids Jehlius cirratus and Notochthamalus scabrosus), sea urchins (Loxechinus albus), chitons (mostly Chiton granosus, secondarily Acanthocpleura echinata) and nudibranchs (1 or 2 species of unidentified Cryptobranchia).
Larval development times vary between 17 and $>30 \mathrm{~d}$ for the mussel species observed in the settlement collectors (Ramorino \& Campos 1979). The species of chthamaloid barnacles reach cypris stage between 20 and $31 \mathrm{~d}$ after hatching (Venegas et al. 2000), and the decapod species reach megalopa stage between 46 and $54 \mathrm{~d}$ after release in the case of Acanthocylcus gayi (Fagetti \& Campodonico 1970) and between 32 and $50 \mathrm{~d}$ in the case of Taliepus dentatus (D. Storch pers. comm.). The sea urchin Loxechinus albus has a development time of about 28 to 34 d in the water (González et al. 1987). Larval duration of Austrolittorina araucana has not been studied in detail, but species of this genus have long-lasting (>30 to $40 \mathrm{~d}$ ) planktonic larvae. There is no information available for Tricolia umbilicata, but members of this genus are direct developers. Larval development of chitons tends to be short, in the order of 7 to $10 \mathrm{~d}$ (Stuardo 1959), and larval development of nudibranchs is usually completed within $1 \mathrm{wk}$ (Brokordt 1995). Thus, all species observed in collectors, with the exception of the few individuals of $T$. umbilicata, have pelagic larvae and are expected to be influenced by physical transport processes that occur beyond the surf zone, including offshore Ekman transport by wind-driven upwelling in this region (Wing et al. 1998, Shanks et al. 2000, Shanks \& Brink 2005). Low numbers of $T$. umbilicata observed in settlement and recruitment data should not have significantly altered observed trends. Information on times of reproduction of the different species is not readily available. We know that mussels Perumytilus purpuratus are reproductive year round with no clear seasonal peaks (M. Fernández unpubl. data). The crabs $A$. gayi and $T$. dentatus are also reproductive year round (Antezana et al. 1965, D. Storch pers. comm.). The chiton Chiton granosus is reproductive year round with a seasonal peak between August and October (M. Fernández unpubl. data). Thus, considering the ample window of reproduction times and larval durations, larvae within most of these taxa can be expected to be found in the water column for several months of the year.

Settlement data were expressed as the average number of ind. collector ${ }^{-1} \mathrm{~d}^{-1}$. To evaluate the correlation between settlement events and upwelling relaxation, we calculated (separately for each taxon) cross correlations between numbers of individuals settling $\mathrm{d}^{-1}$ and sea surface temperature, winds, and upwelling indices. Cross correlations were completed with detrended time series, which evaluated time lags from 0 to $5 \mathrm{~d}$. Standard Pearson correlations (0 lag) among settlement of different taxa were also calculated, and probability values were adjusted for multiple comparisons using sequential Bonferroni correction (PeresNeto 1999). To evaluate simultaneous variation in settlement of all taxa over time, we calculated the 
principal component of days (temporal EOF) using detrended, standardized settlement data for all taxa. Moreover, since we observed discrete, infrequent warming events and marked settlement pulses (see 'Results'), we calculated the probability that 2 or more settlement peaks of different taxa coincided in a given day by simple chance. To this end, we determined when a peak occurred by calculating the long-term daily settlement mean, based on the average of 5 replicates and considering all zeros, and the 95\% confidence interval around the mean. A day of 'significant settlement peak' was then defined as a day in which the number of settlers $\mathrm{d}^{-1}$ surpassed the long-term confidence interval (see Blanton et al. 1995, Ladah et al. 2005). In this manner, settlement of some taxa could occur entirely in 1 or a few settlement peaks, while other taxa could present no settlement peaks (e.g. if individuals trickled in at similar rates throughout the time series). We then ran 1000 randomizations of the position of peaks for each taxa, and calculated the probability of occurrence of $2,3,4,5,6,7$ and 8 settlement pulses of different taxa coinciding on a given date. Changing the confidence interval did not qualitatively alter results.

\section{RESULTS}

\section{Upwelling relaxation and large warming events}

Spring-summer drops in sea surface temperature were associated with intensification of southerly winds (increase in upwelling index) during spring and early summer months, while increases in temperature were generally associated with northerly winds or relaxation of upwelling-favorable conditions (Fig. 2a-c). Good correlations between local wind stress and the upwelling index were observed with a $1 \mathrm{~d}$ time lag (autumn-winter season: $\mathrm{r}=0.58, \mathrm{p}<0.05$; springsummer season: $r=0.41, p<0.05)$. Since the upwelling index reflects regional conditions more closely than local winds, we used the upwelling index as an index of forcing to determine correlations with temperature. Our conclusions were qualitatively unchanged if local wind stress was used instead of the upwelling index. As expected from previous studies (Narváez et al. 2004), surface temperature fluctuations were negatively correlated with upwelling indices, with lags between 1 and $4 \mathrm{~d}(\mathrm{r}=-0.47, \mathrm{p}<0.05)$. Currents measured off Las Cruces (Fig. 2d) also exhibited a classical
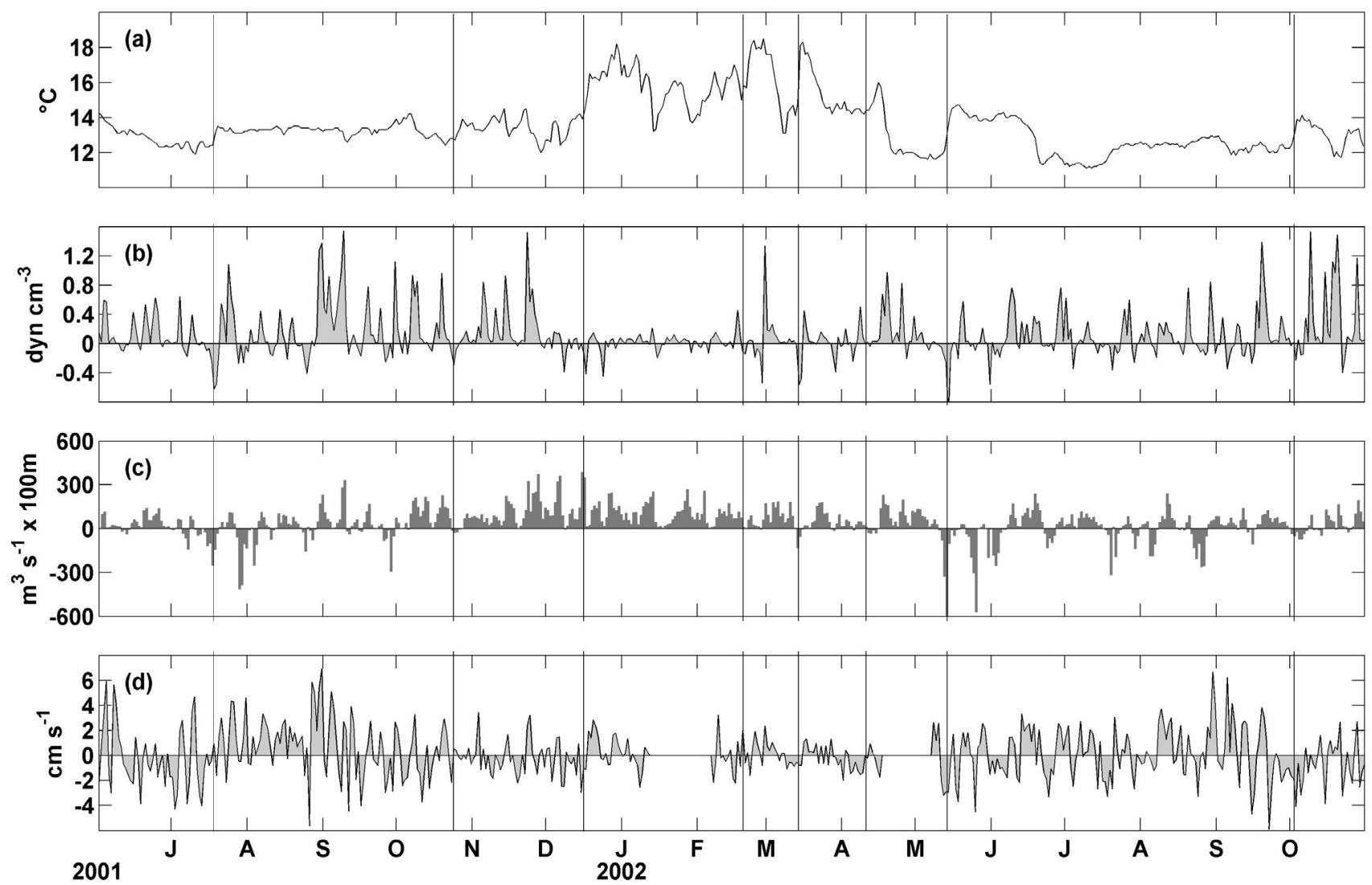

Fig. 2. Time series of (a) temperature at Las Cruces, (b) local wind stress at Las Cruces, (c) 'upwelling index' estimate of offshore Ekman transport at $33^{\circ} \mathrm{S} 74^{\circ} \mathrm{W}$, and (d) alongshore current at coastal mooring. Wind and current data are represented in oceanographic convention (positive values represent northward wind/current); lines demarcate warming events discussed in text 
response to wind forcing: in general, poleward currents occurred when southerly winds weakened, and were especially prevalent during northerly winds (see lines in Fig. 2). Sea surface temperature also responded to surface heating, as was especially evident in the seasonal cycle of temperature associated with seasonal increase of surface heat flux in austral summer months (Fig. 2), which were characterized by a series of warming events that occurred during periods of weak southerly or northerly winds.

Examination of temperature fluctuations for springsummer 1999/2000 (Fig. 3) revealed 2 types of warming events: (1) frequent events with small temperature increases $\left(<1^{\circ} \mathrm{C}\right)$ confined to surface waters, i.e. stratification was maintained or increased, and (2) infrequent events with large temperature increases $\left(>3^{\circ} \mathrm{C}\right)$ that resulted in an isothermal water column to depths $\sim 20 \mathrm{~m}$, i.e. stratification broke down in shallow waters $(<20 \mathrm{~m})$.

The first large warming event developed during a rapid increase in temperature between 26 November and 2 December 1999, which followed a relaxation of $1 \mathrm{wk}$ of moderate upwelling winds (dashed lines, Fig. 3). The second event occurred between 24 January and 2 February, but in this case temperature steadily increased by about $4^{\circ} \mathrm{C}$ over a relatively long period of $9 \mathrm{~d}$. In this case, strong upwelling conditions relaxed to nearly neutral conditions over a period of a few days (Fig. 3).

During summer 2002, we again observed frequent small temperature increases of $\leq 1^{\circ} \mathrm{C}$ and 2 large warming events (Fig. 4). Temperature data from the oceanic mooring available for this period clearly showed well-defined stratification over the inner shelf and close correlation with temperature fluctuations observed at the coastal mooring at zero lag (Fig. 4a,b; $r>0.85, p<0.05$ for the entire period and all depth comparisons between coastal and oceanic moorings, except $90 \mathrm{~m}$ depth). Again, stratification of the water column was preserved during small temperature increases, whereas an isothermal water column was observed during the 2 large warming events (dashed lines in Fig. 4). At the offshore mooring, the water column was isothermal to $>25 \mathrm{~m}$ but did not extend to $90 \mathrm{~m}$. In fact, water temperature at $90 \mathrm{~m}$ depth remained constant at about $11^{\circ} \mathrm{C}$ throughout this season, and was not correlated to fluctuations observed in the upper water column $(\mathrm{r}<0.26, \mathrm{p}>0.05)$.

The first of these large warming events occurred between 19 and 23 February 2002, when an initial drop in temperature, apparently produced by the intensification of southerly winds (large upwelling indices), was followed by an increase of about $3^{\circ} \mathrm{C}$ after the relaxation of winds (values near 0 in Fig. 4c).
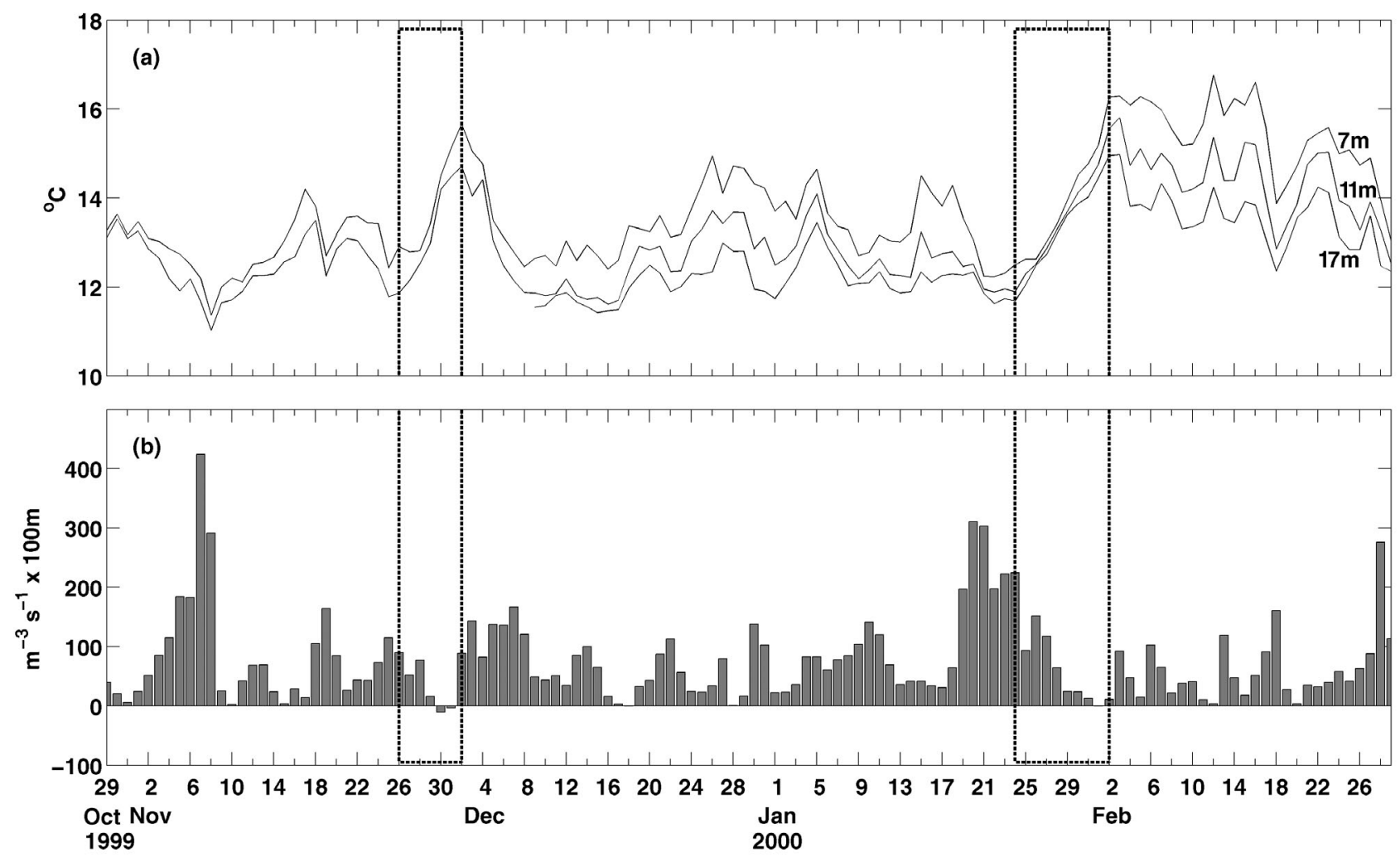

Fig. 3. Time series of (a) temperature at coastal mooring, and (b) 'upwelling index' estimate of offshore Ekman transport at $33^{\circ} \mathrm{S} 74^{\circ} \mathrm{W}$ for spring-summer 1999/2000. Dashed lines demarcate large warming events discussed in text 

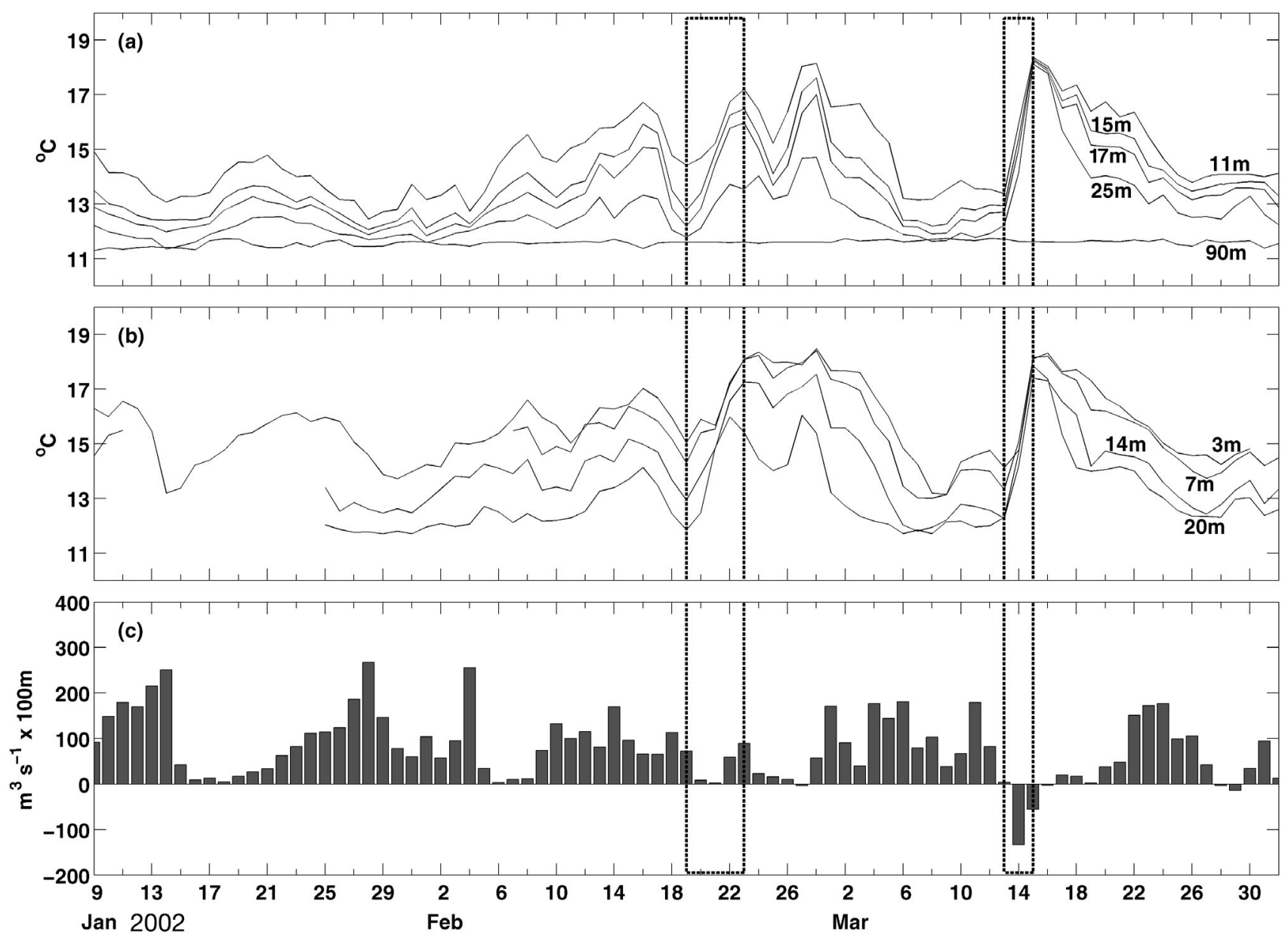

Fig. 4. Time series of (a) temperature at oceanic mooring, (b) temperature at coastal mooring, and (c) 'upwelling index' estimate of offshore Ekman transport at $33^{\circ} \mathrm{S} 74^{\circ} \mathrm{W}$ for summer 2002. Dashed lines demarcate large warming events discussed in text

The second large warming event occurred between 13 and 15 March, when temperature rapidly increased by more than $3^{\circ} \mathrm{C} \mathrm{d}^{-1}$. In this case, winds reversed to be strong and downwelling-favorable at the beginning of the warming event, and the reversal of wind conditions was observed at local stations as well as in upwelling indices (Figs. 2b,c \& 4c). As in springsummer 1999/2000, other wind relaxation events were observed (e.g. 8 to 18 November 1999; 2 to 5 January $2000 ; 15$ to 17 January 2002; 5 to 8 February 2002) that lead to small temperature increases without producing large warming events nearshore or offshore. Overall, cross-correlation analyses showed that surface temperature in this period was significantly correlated with the upwelling index with a $2 \mathrm{~d}$ time lag $(\mathrm{r}=0.55$, $p<0.05)$. Examination of hourly data suggests that there was a time lag in the occurrence of large warming events between coastal and oceanic moorings, but this time lag was difficult to quantify because of the presence of a diurnal signal produced by solar heating in the hourly records.
While surface heating may explain observed temperature increases during small relaxation events, surface heating was not strong enough to account for the observed increase in temperature over depth during large warming events. The percentage of observed heat increase explained by net surface heat flux (largely determined by direct solar radiation) is shown in Table 1 . These percentages were low in the case of large warming events, indicating that advection (import) of warmer waters was necessary to produce the observed heat gain during large warming events. This was true also for some of the rapid small warming events, suggesting that advection was also important during those events.

\section{Spatial scale of warming events}

In order to characterize the alongshore extent of large warming events, we reviewed AVHRR satellite images of surface temperature for 3 different large warming events (Fig. 5) and coastal temperature along 
Table 1. Comparison between water column heat content and net incoming heat flux $\left(10^{8} \mathrm{~J} \mathrm{~m}^{-2}\right)$ (largely due to direct solar radiation) for spring-summer 1999/2000 and summer 2002. Dates in bold indicate occurrence of large warming events; other dates are periods of small temperature increases in water column. Percentage is fraction of total heat content of the water column that can be explained by surface heat flux integrated over the period of warming

\begin{tabular}{|c|c|c|c|c|c|c|c|}
\hline & \multicolumn{3}{|c|}{ Spring-summer 1999/2000 } & & \multirow[b]{2}{*}{ Heat content } & \multirow{2}{*}{$\begin{array}{l}\text { Summer } 2002 \\
\text { Net incoming } \\
\text { flux }\end{array}$} & \multirow[b]{2}{*}{ Percentage } \\
\hline & Heat content & $\begin{array}{l}\text { Net incoming } \\
\text { flux }\end{array}$ & Percentage & & & & \\
\hline $\begin{array}{l}08 \text { Nov } 1999 \\
17 \text { Nov } 1999\end{array}$ & 2.36 & 2.13 & 90 & $\begin{array}{l}19 \text { Feb } 2002 \\
23 \text { Feb } 2002\end{array}$ & 5 & 0.5 & 10 \\
\hline $\begin{array}{l}26 \text { Nov } 1999 \\
02 \text { Dec } 1999\end{array}$ & 2.38 & 1.14 & 48 & $\begin{array}{l}25 \text { Feb } 2002 \\
28 \text { Feb } 2002\end{array}$ & 1.3 & 0.3 & 23 \\
\hline $\begin{array}{l}16 \text { Dec } 1999 \\
18 \text { Dec } 1999\end{array}$ & 0.8 & 0.7 & 88 & $\begin{array}{l}13 \text { Mar } 2002 \\
15 \text { Mar } 2002\end{array}$ & 6 & 0.08 & 1 \\
\hline $\begin{array}{l}\text { 03 Jan } 2000 \\
\text { 05 Jan } 2000\end{array}$ & 1.1 & 0.7 & 64 & & & & \\
\hline $\begin{array}{l}14 \text { Jan } 2000 \\
15 \text { Jan } 2000\end{array}$ & 1.1 & 0.5 & 45 & & & & \\
\hline $\begin{array}{l}24 \text { Jan } 2000 \\
02 \text { Feb } 2000\end{array}$ & 3.5 & 2 & 57 & & & & \\
\hline $\begin{array}{l}10 \text { Feb } 2000 \\
12 \text { Feb } 2000\end{array}$ & 1.3 & 0.2 & 15 & & & & \\
\hline
\end{tabular}
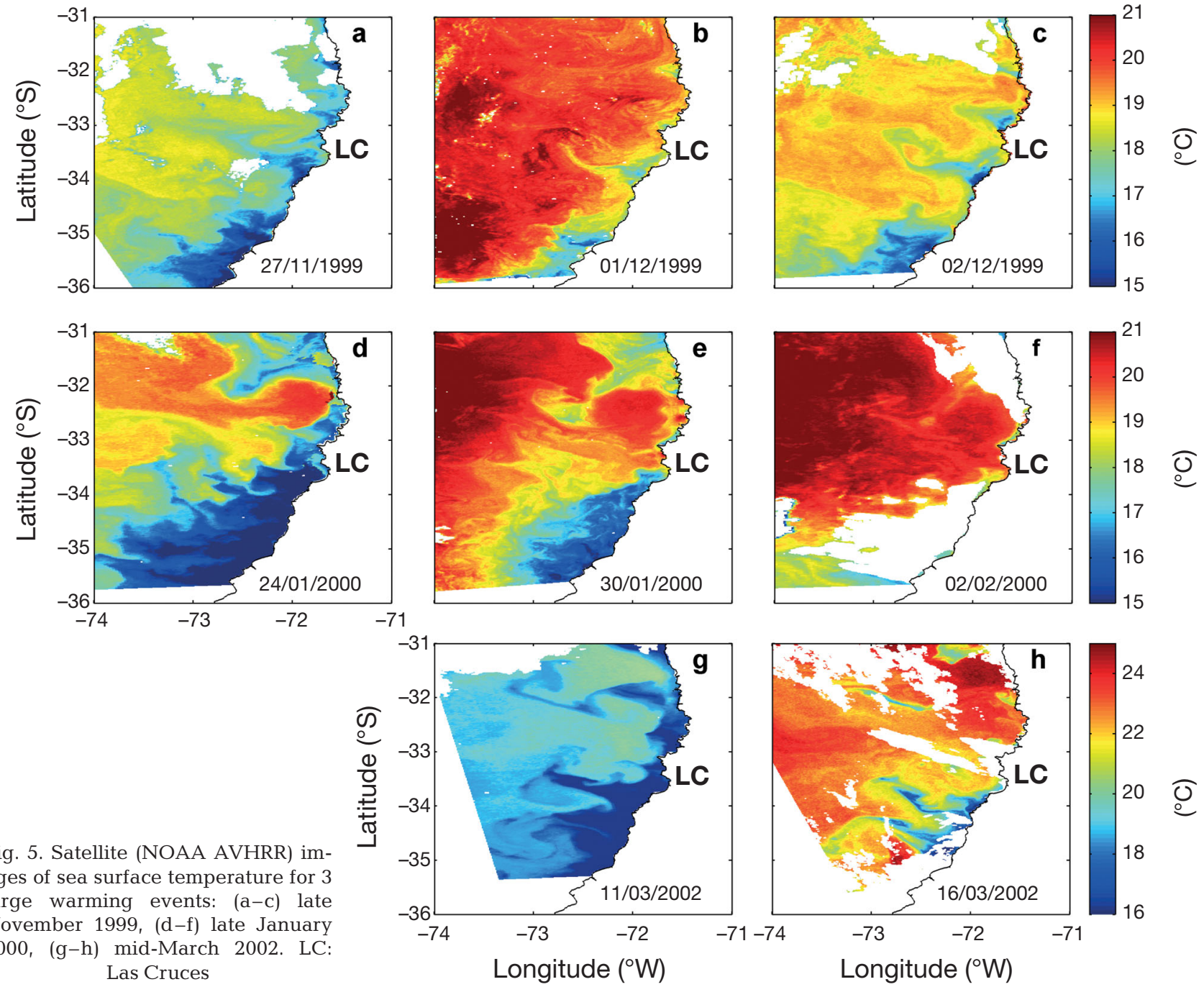

Fig. 5. Satellite (NOAA AVHRR) images of sea surface temperature for 3 large warming events: $(\mathrm{a}-\mathrm{c})$ late November 1999, (d-f) late January 2000, (g-h) mid-March 2002. LC: Las Cruces 

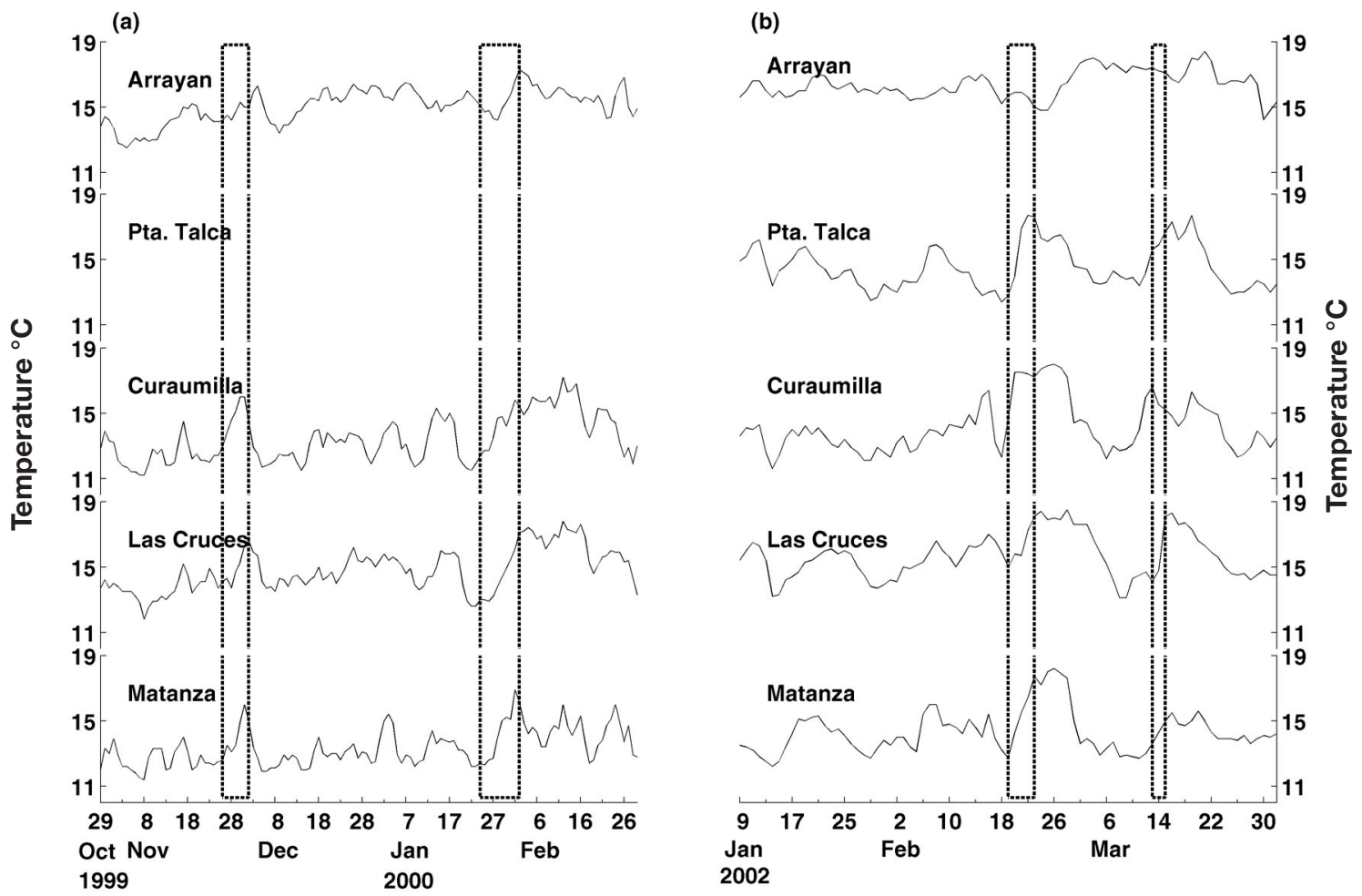

Fig. 6. Time series of temperature at rocky sites along central Chile for (a) spring-summer 1999/2000, and (b) summer 2002. Dashed lines demarcate large warming events discussed in text

central Chile (Fig. 6). During spring-summer upwelling conditions, areas of cold and recently upwelled waters alternated alongshore with smaller areas of warm water (Fig. 5a,d). At the onset of relaxation, these small coastal patches of warm water may have advected short distances alongshore, affecting limited alongshore scales, but in the absence of shoreward intrusions of offshore water the coastal warming effect was weak and not widespread. In contrast, during relaxation that leads to notable large warming events, warm offshore waters $\left(\sim 20^{\circ} \mathrm{C}\right)$ moved onshore and contacted the coast over long distances (>100 km alongshore), specifically in the entire region between 31 and $36^{\circ} \mathrm{S}$ (Figs. 5b,c,e,f $\& 6)$. While localized cold waters may have continued to be observed at some locations (e.g. around $35^{\circ} \mathrm{S}$, but also in smaller patches at Punta Toro and Punta Curaumilla), these locations were exceptions to the widespread warming effect of onshore advection. Las Cruces appeared to be a site of strong onshore advection-one of the first locations where this warm water makes landfall (Figs. $5 \& 6$ ). Further, at a more regional scale, warm waters appeared to first contact the coast in the northern part of the study area $\left(31\right.$ to $\left.34^{\circ} \mathrm{S}\right)$ and later impact the southern parts $\left(34\right.$ to $\left.36^{\circ} \mathrm{S}\right)$, where upwelling persisted longer (Fig. 6). Under these relaxation conditions, cross-shore and alongshore thermal gradients were very weak.

\section{Invertebrate settlement}

The different invertebrate taxa exhibited widely different patterns (timing, frequency) and magnitudes (rates) of daily settlement (Fig. 7). Some taxa settled throughout the period between October 1999 and February 2000 with numerous peaks (e.g. mussels, decapods), while others settled in 1 or 2 discrete pulses (e.g. sea urchins, barnacles). In general, low and not significant correlations were found among settlement time series $(r<0.25, p \geq 0.05)$, with the exception of the settlement correlations between sea urchins and chitons $(r=0.7)$, sea urchins and decapods $(r=0.47)$, decapods and gastropods $(\mathrm{r}=0.29)$, decapods and chitons $(\mathrm{r}=0.28)$, and nudibranches and chitons ( $\mathrm{r}=$ 0.27 ), which were positively correlated at $\mathrm{p}<0.05$ after sequential Bonferroni correction.

Statistical analyses did not show any quantitative relationship between settlement rate and temperature or upwelling indices (all taxa and all time lags analyzed: $\mathrm{r}<0.1, \mathrm{p} \geq 0.05$ ). Redefining 'significant settlement peaks' using long-term confidence intervals did not improve the correlation with temperature fluctuations, suggesting that the upwelling-relaxation transport model does not influence invertebrate settlement in a simple manner at Las Cruces. Similarly, no significant correlations were observed between settlement 


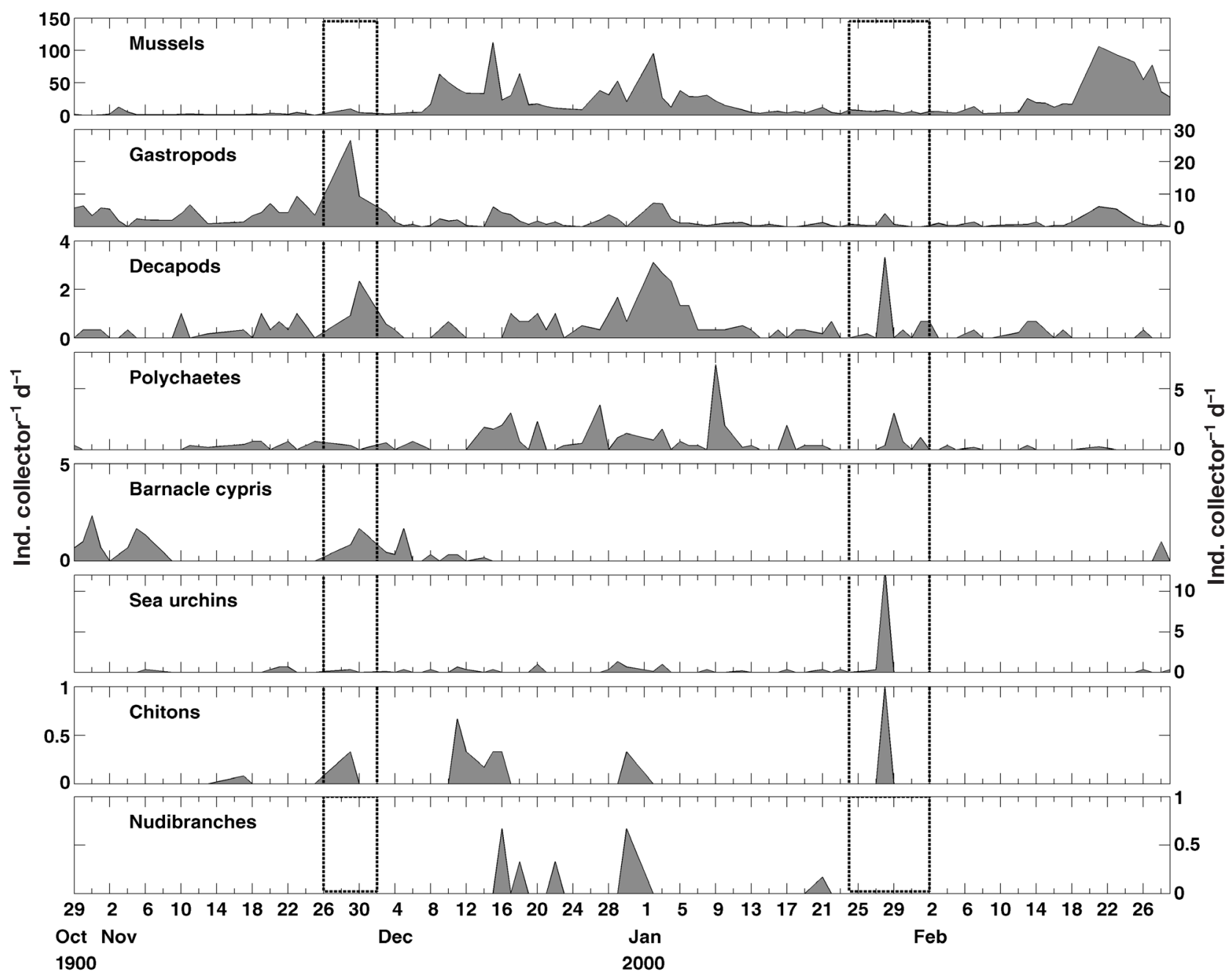

Fig. 7. Daily settlement of marine invertebrate larvae expressed as average number of ind. collector ${ }^{-1} \mathrm{~d}^{-1}$. Dashed lines demarcate large warming events discussed in text

and alongshore winds. The only exception was a weak, significantly negative correlation between gastropod settlement and upwelling indices $(\mathrm{r}=-0.26,-0.24$, $-0.25, \mathrm{p}<0.05$ for 0,1 and $2 \mathrm{~d}$ lags).

During the 2 large warming events observed during this period, there was synchrony in the settlement of several different invertebrate taxa (Figs. 7 \& 8); i.e. between 27 November and 1 December there was a 'significant settlement peak' of gastropods, decapods, barnacles, and chitons $(\sim 2, \sim 30, \sim 2$ and $\sim 0.5$ ind. collector $^{-1} \mathrm{~d}^{-1}$, respectively), and from 27 to 30 January there was a significant settlement peak of gastropods, decapods, polychaetes, sea urchins, and chitons $\left(\sim 5, \sim 4, \sim 2, \sim 10\right.$ and $\sim 1$ ind, collector ${ }^{-1} \mathrm{~d}^{-1}$, respectively). Comparison against a null model of synchrony in settlement, conducted by independently randomizing the occurrence of significant settlement peaks, showed that synchrony of more than 4 peaks occurred less than
$5 \%$ of the time by simple chance, and synchrony of 5 peaks occurred less than $2 \%$ of the time by chance alone (Fig. 8). Thus, large warming events seem to produce significant synchrony in settlement of a large number of invertebrate taxa, even though for several taxa these settlement pulses were not particularly large in comparison to other settlement events (e.g. decapods, gastropods). High levels of synchrony were also observed at other times, which have been associated with strong stratification of the water column and internal wave activity (Vargas et al. 2004). The time series of principal components 1 and 2, which explained $27 \%$ and $17 \%$ of the variance, respectively, also showed the 2 important synchronies in the settlement composition (abundances of all taxa) at the time of warming events (Fig. 8). However, no significant correlation was observed between the principal components and physical variables $(\mathrm{r}<0.2, \mathrm{p}>0.05)$. 


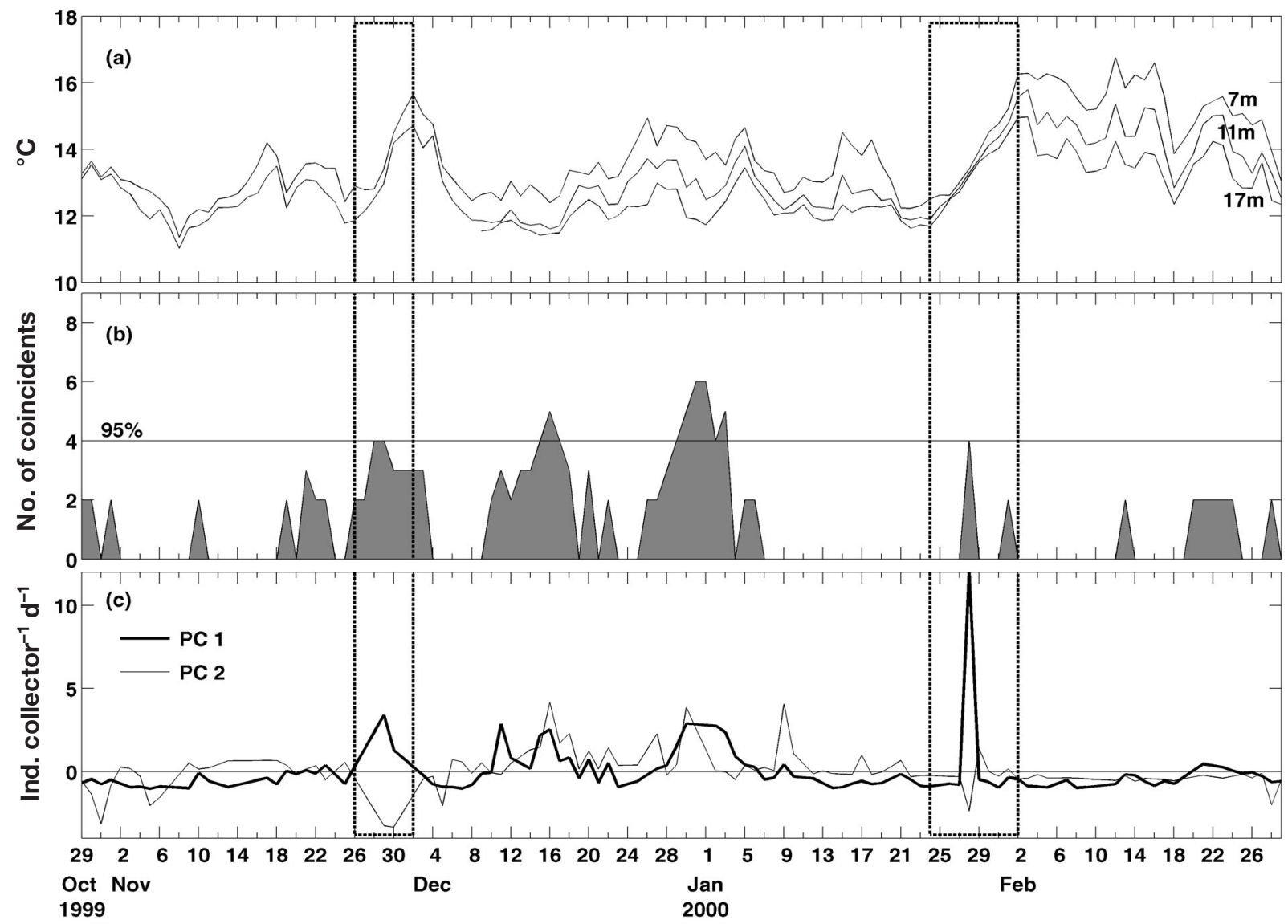

Fig. 8. Time series of (a) temperature at coastal mooring, (b) number of taxa settled coincidentally ( $\mathrm{d}^{-1}$ ) and level of significance (horizontal line, $95 \%$ ), and (c) principal components of settlement. All data for spring-summer 1999/2000; dashed lines demarcate large warming events discussed in text

\section{DISCUSSION}

Our results showed that multi-day fluctuations in sea surface temperature were associated with fluctuations in alongshore winds, i.e. synoptic variability. Significant negative cross-correlations for both springsummer 1999/2000 and summer 2002 showed that intensification of southerly winds caused a temperature drop, and that weak winds and northerly winds resulted in higher temperatures (see Figs. 2-4). While the nature of these warming events exhibited significant variability, there were essentially 2 types:

Small temperature increases during relaxation: these were most common, with increases of 0.5 to $1^{\circ} \mathrm{C}$ explainable by surface heating and local advective fluxes. These events tended to be short-lived, and warming was near-surface so that increased stratification of the nearshore water column was observed

Large temperature increases during relaxation: these were less common, but at least 2 were observed in each spring-summer period. These 'large warming events' were more marked, lasted a number of days, and attained temperature increases of $3^{\circ} \mathrm{C}$ throughout the uppermost $25 \mathrm{~m}$ of the water column. Further, they were observed simultaneously over large distances (100 km or more) along the central coast of Chile (30 to $35^{\circ} \mathrm{S}$ )

In contrast to smaller warming events, which can be explained by surface heating and moderate amounts of heating owing to along or cross-shore advection, the large warming events represented large heat gains ( 2 to $6 \times 10^{8} \mathrm{~J} \mathrm{~m}^{-2}$ ). Surface heating accounted for no more than half of the heat gained during the large warming events (see Table 1), which suggested that the majority of heat gained came from advection. These results were consistent with prior studies in California, where large temperature increases have been ascribed to advective heat fluxes with only a secondary contribution from surface heat fluxes (e.g. Send et al. 1987, Largier et al. 1993, Wing et al. 1995a). However, in contrast to these northern California examples of alongshore advection of warm waters from a sheltered embayment (Gulf of Farallones), here we observed synchronous temperature increases rather than a propagating temperature increase, indicating onshore advection of warmer offshore waters - more comparable 
with the Monterey Bay scenario described by Roughgarden et al. (1991). A more detailed analysis would include data from a spatial array of meteorological and oceanographic mooring, data that are not readily available for our study area.

While the nature and dynamics of these large warming events were not resolved in this study, it seems that there is a link to the mesoscale eddy field in the Humboldt Current System. The widespread nature of the large warming events observed in this study corresponded well with the spatial scale of eddies reported for this area and with the latitudinal break of mesoscale eddy activity at 29 to $30^{\circ} \mathrm{S}$ (Hormazabal et al. 2004). Recent studies have shown that mesoscale eddies are particularly active offshore of this study area (Leth \& Shaffer 2001, Hormazabal et al. 2004). In addition, results from California suggest that offshore waters move shoreward in preferred regions along the coast (e.g. Roughgarden et al. 1991, Largier et al. 1993). It appears that the intrusion of warm water to the shore, like the 'large warming events' reported in this work, depends on certain conditions in terms of both mesoscale eddy features and coastal winds, in conjunction with local topography.

\section{Settlement and upwelling relaxation}

Several studies have shown the importance of upwelling relaxation to onshore transport of competent (ready to settle) larvae of invertebrates. For instance, Morgan et al. (2000) observed that flows generated during a relaxation event distributed competent larvae of red sea urchins along the shore off northern California, while Shanks et al. (2000) showed evidence that high concentrations of larvae off North Carolina can be transported to the inner shelf by shoreward propagation of the upwelling front during relaxation. Also, Wing et al. (1995a) have described alongshore transport of decapod megalopae during relaxation off northern California, which resulted in alongshore structure in settlement patterns in that region. Farrell et al. (1991) and Roughgarden et al. (1991) described settlement of barnacles along the Monterey Bay shoreline (California) associated with relaxation and downwelling conditions.

Although coastal surface temperature responded quickly to the relaxation of upwelling winds (1 to $2 \mathrm{~d}$ ), we did not obtain a clear quantitative correlation between relaxation events and settlement for most of the invertebrate taxa at our study site-the one exception being the weak correlation obtained for gastropods. This contrasts with patterns reported for other upwelling coasts (see above), which involved different species but the same taxa (e.g. decapods, barnacles, polychaetes). The lack of correlation indicated that smaller relaxation events do not necessarily result in consistent settlement onshore, at least during the period of this study. Therefore, other mechanisms such as internal tidal bores (Vargas et al. 2004) and seabreeze-driven river plumes and plume fronts (Kaplan et al. 2003, Piñones et al. 2005) could play a role in larval transport to the shoreline.

Spatial variability in the timing of settlement could be important, and further studies should address this issue. Our observations were localized (at 1 point) and might not provide a good representation of timing of settlement at nearby sites. Studies observing recruitment of these same taxa every $15 \mathrm{~d}$ along this same shore have found high levels of synchrony over several km (Lagos et al. 2005, S. Navarrete unpubl. data). However, synchrony of individual settlement events has not been investigated and needs to be addressed to determine the generality of our results.

During the infrequent large warming events (2 to 3 times $\mathrm{yr}^{-1}$ ), simultaneous settlement of several distinct invertebrate taxa (e.g. decapods, polychaetes, urchins, gastropods, chitons) was observed. Synchrony of settlement across taxa was significantly higher than expected by chance alone, suggesting that a common process (or suite of processes associated with this feature) transports a wide variety of competent larvae onshore. The large spatial scale of these events (alongshore, cross-shore, and in depth) and effective onshore transport of larvae with different behaviors suggests the existence of an offshore 'larval pool' for many taxa. These coincident settlement events represent a major peak for some taxa (e.g. urchins, chitons), but only one of many pulses for other taxa (e.g. decapods).

Our results indicated that, in this case, a simple upwelling-relaxation model (e.g. Roughgarden et al. 1988) is not generally appropriate for the determination of larval transport. While spatial patterns of recruitment (bi-weekly observations) of chthamaloid barnacles over a stretch of $120 \mathrm{~km}$ in central Chile can be explained in part by alongshore variation in upwelling intensity (Lagos et al. 2005), our results suggested that the upwelling-relaxation mechanism does not directly transport invertebrate larvae onshore to intertidal habitats. The pattern described by Lagos et al. (2005) might be the result of differences in larval concentration or larval retention influenced by upwelling, and not by the transport back to shore. In particular, where relaxation results in a diversity of flow patterns, one cannot expect a simple relationship between relaxation and settlement. In this region, it is only during a few events a year that larvae in offshore waters seem to be transported back to the shoreline in a coherent event. In Monterey Bay, it appears that similar shoreward transport occurs more regularly, 
either due to the proximity or persistence of warm mesoscale features off the mouth of the Bay, or due to specific circulation that favors onshore transport at this latitude (which lies between 2 upwelling centers). Significant correlations have also been observed north of Point Reyes (Wing et al. 1995a), and although the mechanism is different along the northern California coast (it is characterized by alongshore transport of warm megalopae-rich waters from south of the Point), there is again a dominance of one type of relaxation flow. In central Chile, there are 2 distinct types of relaxation events: one type brings offshore surface waters to the shore (and results in concurrent settlement of many taxa), and the other type does not (and settlement patterns are more variable). This demonstrates the importance of exploring settlement patterns and upwelling activity at sites with different coastal orientation and topography (e.g. Nielsen \& Navarrete 2004), and understanding the comparative processes and patterns of settlement associated with relaxation of upwelling forcing.

\section{Metapopulation implications}

Even though our results should be considered with caution due to the small number of events that occurred in coincidence with settlement observations, we suspect that large warming events are important to larval dispersal and metapopulation structure in central Chile. Although settlement due to shoreward transport of offshore surface water may not dominate the settlement numbers for all taxa, it does seem to be important for some taxa. Further, for all taxa, these events present an opportunity for settlement of larvae spawned at distant sites. The large and active mesoscale structures in the Humboldt Current allow for alongshore diffusive fluxes that are much greater than in coastal waters (Largier 2003), and can provide an opportunity for some larvae that have been spawned at distances of several hundred $\mathrm{km}$ to be transported to these settlement sites within typical planktonic larval durations. Thus, onshore flow represents an opportunity for onshore transport from an offshore larval pool: a mix of larvae spawned throughout the metapopulation (or a large part of it). However, if the intensity/ frequency of these mesoscale structures is different north and south of about 30 to $32^{\circ} \mathrm{S}$, as suggested by Hormazabal et al. (2004) and our own study (Navarrete et al. 2002), then one could expect differences in the genetic structure of populations across this region. Thus, while this study suggested that a classical 'larval pool' (Roughgarden et al. 1985) may be important for benthic metapopulations, it also suggested that this larval pool would have a regional structure influenced by the offshore mesoscale eddy field. Given the importance of such a larval pool for metapopulation structure, this suggestion merits further investigation in the Humboldt and other upwelling regions.

Acknowledgements. We thank R. Venegas for his help in the collection and identification of settlement samples, and M. Fernández and D. Storch for sharing unpublished information on reproduction and larval duration of invertebrates. Comments by 4 anonymous referees greatly improved the presentation of our ideas. This research was supported by Proyecto Italia (CICS-EULA Genova-PUCCH), an Andrew Mellon Foundation grant to S.A.N. and J. C. Castilla, and FONDAP Oceanografía \& Biología Marina $\mathrm{N}^{\circ} 3$ to S.A.N. We also appreciate support from FONDAP-FONDECYT grant 15001-001 to the Center for Advanced Studies in Ecology and Biodiversity, Pontificia Universidad Católica de Chile, which allowed us to complete this study. J.L.L. was supported by the National Science Foundation through grants from the Ocean Sciences Division. The continuous support of the Andrew Mellon Foundation to foster international collaborations is greatly appreciated.

\section{LITERATURE CITED}

Antezana T, Fagetti E, Lópes MT (1965) Observaciones bioecológicas en decapodos comunes de Valparaíso. Rev Biol Mar 12:1-60

Austin JA, Lentz SJ (2002) The inner shelf response to winddriven upwelling and downwelling. J Phys Oceanogr 32: 2171-2193

Blanton J, Wenner E, Werner F, Knott D (1995) Effects of windgenerated coastal currents on the transport of blue crab megalopae on a shallow continental shelf. Bull Mar Sci 57:739-752

Brokordt K (1995) Intensidad reproductiva y desarrollo intracapsular de tres especies de nudibranquios presentes en la IV Región de Chile (Anisodoris rudberghi, Phidiana inca y Thecacera darwini), y su relación con la estrategia de alimentación larval. Undergraduate thesis, Universidad Católica del Norte, Sede Coquimbo

Cáceres M, Arcos D (1991) Variabilidad en la estructura espaciotemporal de un área de surgencia frente a la costa de Concepción, Chile. Invest Pesq (Chile) 36:27-38

Castilla JC, Paine RT (1987) Predation and community organization on Eastern Pacific, temperate zone, rocky intertidal shores. Rev Chil Hist Nat 60:131-151

Fagetti E, Campodonico I (1970) Desarrollo larval en el laboratorio de Acanthocylcus gayi Milne-Edwards et Lucas (Crustacea Bracyura; Atelecyclidae, Acanthocyclinae). Rev Biol Mar 14: $63-78$

Farrell T, Bracher D, Roughgarden J (1991) Cross-shelf transport causes recruitment to intertidal populations in central California. Limnol Oceanogr 36:279-288

Fernández M, Jaramillo E, Marquet P, Moreno C, Navarrete S, Ojeda P, Valdovinos C, Vásquez J (2000) Diversity, ecology and biogeography of Chilean benthic nearshore ecosystems: an overview and needs for conservation. Rev Chil His Nat 73: $629-662$

Figueroa D, Moffat C (2000) On the influence of topography in the induction of coastal upwelling along the Chilean coast. Geophys Res Lett 27:3905-3908

Garland ED, Zimmer CA, Lentz SJ (2002) Larval distributions in inner-shelf waters: the roles of wind-driven cross-shelf currents and diel vertical migrations. Limnol Oceanogr 47:803-817

Gill AE (1982) Atmosphere-ocean dynamics. Academic Press, New York 
González LP, Castilla JC, Guisado CH (1987) Effect of larval diet and rearing temperature on metamorphosis and juvenile survival of the edible sea urchin Loxechinus albus (Molina 1782) (Echinoidea, Echinidae). J Shellfish Res 6:109-115

Graham WM, Largier JL (1997) Upwelling shadows as nearshore retention sites: the example of northern Monterey Bay. Cont Shelf Res 17:509-532

Hormazabal S, Shaffer G, Leth O (2004) The coastal transition zone off Chile. J Geophys Res 109, C01021, doi:10.1029/2003 JC001956

Huyer A (1983) Upwelling in the California Current system. Prog Oceanogr 12:259-284

Kaplan DM, Largier JL, Navarrete SA, Guiñez R, Castilla JC (2003) Large diurnal temperature fluctuations in the nearshore water column. Estuar Coast Shelf Sci 57:385-398

Ladah LD, Tapia FJ, Pineda J, López M (2005) Spatially heterogeneous, synchronous settlement of Chthamalus spp. larvae in northern Baja California. Mar Ecol Prog Ser 302:177-185

Lagos N, Navarrete SA, Véliz, F, Masuero A, Castilla JC (2005) Meso-scale spatial variation in settlement and recruitment of intertidal barnacles along the coast of central Chile. Mar Ecol Prog Ser 290:165-178

Largier JL (2003) Considerations in estimating larval dispersal distance from oceanographic data. Ecol Appl 13:S71-S89

Largier JL, Magnell BA, Winant CD (1993) Subtidal circulation over the northern California shelf. J Geophys Res 98(C10): 18147-18179

Leth O, Shaffer G (2001) A numerical study of the seasonal variability in the circulation off central Chile. J Geophys Res 106(C10):22229-22248

Lipcius RN, Crowder LB, Morgan LE (2005) Metapopulation structure and marine reserves. In: Norse E, Crowder LB (eds) Marine conservation biology. Island Press, Washington, DC, p 328-345

Morgan LE, Wing SR, Botsford LW, Lundquist CJ, Diehl JM (2000) Spatial variability in red sea urchin (Strongylocentrotus franciscanus) recruitment in northern California. Fish Oceanogr 9: 83-98

Narváez DA, Poulin E, Leiva G, Hernández E, Castilla JC, Navarrete SA (2004) Seasonal and spatial variation of nearshore hydrographic conditions in central Chile. Cont Shelf Res 24: 279-292

Navarrete SA, Broitman BR, Wieters EA, Finke GR, Venegas RM, Sotomayor A (2002) Recruitment of intertidal invertebrates in the southeast Pacific: interanual variability and the 1997-1998 El Niño. Limnol Oceanogr 47:791-802

Nielsen KJ, Navarrete SA (2004) Mesoscale regulation comes from the bottom-up: intertidal interactions between consumers and upwelling. Ecol Lett 7:31-41

Ogden JC (1997) Marine managers look upstream for connections. Science 278:1414-1415

Peres-Neto PR (1999) How many statistical tests are too many? The problem of conducting multiple ecological inferences revisited. Mar Ecol Prog Ser 176:303-306

Pineda J (1991) Predictable upwelling and the shoreward transport of planktonic larvae by internal tidal bores. Science 253: $548-551$

Pineda J (1995) An internal tidal bore regime at nearshore stations along western U.S.A.: predictable upwelling within the lunar cycle. Cont Shelf Res 15:1023-1041

Pineda J (1999) Circulation and larval distribution in internal tide bore warm fronts. Limnol Oceanogr 44:1400-1414

Piñones A, Valle-Levinson A, Narváez DA, Vargas CA, Navarrete SA, Yuras G, Castilla JC (2005) Wind-induced diurnal variability in river plume motion. Estuar Coast Shelf Sci 65: $513-525$
Ramorino L, Campos B (1979) Desarrollo larval y postlarval de Perumyttlus purpuratus (Lamarck, 1819). Bivalvia: Mytilidae. Ann Mus Hist Nat 12:207-218

Roughgarden J, Iwasa Y, Baxter C (1985) Demographic theory for an open marine population with space-limited recruitment. Ecology 66:54-57

Roughgarden J, Gaines S, Possingham H (1988) Recruitment dynamics in complex life cycles. Science 241:1460-1466

Roughgarden J, Pennington JT, Stoner D, Alexander S, Miller K (1991) Collisions of upwelling fronts with the intertidal zone, the cause of recruitment pulses in the barnacle populations of central California. Acta Oecol 12:35-51

Send U, Beardsley RC, Winant CD (1987) Relaxation from upwelling in the Coastal Dynamics Experiment. J Geophys Res 92(C2):1683-1698

Shanks AL (1986) Tidal periodicity in the daily settlement of intertidal barnacle larvae and an hypothesized mechanism for the cross-shelf transport of cyprids. Biol Bull (Woods Hole) 170:429-440

Shanks AL, Largier JL, Brink L, Brubaker J, Hoff H (2000) Evidence for shoreward transport of meroplankton by an upwelling relaxation front. Limnol Oceanogr 45:230-236

Smith RL (1995) The physical processes of coastal ocean upwelling systems. In: Summerhayes CP, Emeis KC, Anel MV, Smith RL, Zeitzchel B (eds) Upwelling in the ocean: modern processes and ancient records. John Wiley \& Sons, New York, p 39-64

Sobarzo M, Djurfeldt (2004) Coastal upwelling process on a continental shelf limited by submarine canyons, Concepción, central Chile. J Geophys Res 109, C12012, doi:10.1029/ 2004JC002350

Strub PT, Mesías JM, Montesinos V, Rutllant J, Salinas S (1998) Coastal ocean circulation off western South America. In: Robinson AR, Brink KH (eds) The sea, Vol 11. J Wiley \& Sons, New York, p 273-313

Stuardo J (1959) Ensayo de una clave de familias y géneros chilenos de Polyplacophora, con generalidades del grupo e inclusión de algunas especies comunes. Invest Zool Chil 5:139-148

Thomas AC (1999) Seasonal distributions of satellite-measured phytoplankton pigment concentration along the Chilean coast. J Geophys Res 104(C11):25877-25890

Thorson G (1950) Reproductive and larval ecology of marine bottom invertebrates. Biol Rev Camb Phil Soc 25:1-45

Vargas CA, Narváez DA, Piñones MA, Venegas R, Navarrete SA (2004) Internal tidal bore warm fronts and settlement of invertebrates in central Chile. Estuar Coast Shelf Sci 61:603-612

Venegas RM, Ortiz V, Olguín A, Navarrete SA (2000) Larval development of the intertidal barnacles Jehlius cirratus and Notochthamalis scabrosus (Cirripedia: Chthamaloidea) under laboratory conditios. J Crustac Biol 20:495-504

Wieters EA, Kaplan DM, Sotomayor A, Navarrete SA, Largier JL, Nielsen KJ, Véliz F (2003) Alongshore and temporal variability in chlorophyll a concentrations in Chilean nearshore waters. Mar Ecol Prog Ser 249:93-105

Wing SR, Botsford LW, Largier JL, Morgan LE (1995a) Spatial structure of relaxation events and crab settlement in the northern California upwelling system. Mar Ecol Prog Ser 128: 199-211

Wing SR, Largier JL, Botsford LW, Quinn LF (1995b) Settlement and transport of benthic invertebrates in an intermittent upwelling region. Limnol Oceanogr 40:316-329

Wing SR, Botsford LW, Ralston SV, Largier JL (1998) Meroplanktonic distribution and circulation in a coastal retention zone of the northern California upwelling system. Limnol Oceanogr 43:1710-1721 
Appendix 1. Estimations of water column heat content and net surface heat flux

We estimated the difference in water column heat content $(H)$ at the beginning and end of small and large warming events, and compared these results against bulk estimates of the net surface heat flux integral over the days in which warming events occurred. With these estimates, we calculated the percentage of $H$ that could be explained by net surface flux and interpreted the residual as being due to near-surface advective heat fluxes.

Heat content was obtained by integrating the water column temperature using the following relationship:

$$
H=\int \rho C p T \mathrm{~d} z
$$

where $\rho=1025 \mathrm{~kg} \mathrm{~m}^{-3}$ and $C p=4814 \mathrm{~J} \mathrm{~kg}^{-1}{ }^{\circ} \mathrm{C}^{-1}$ (Send et al. 1987). In order to compare our estimates for spring-summer 1999/2000 and summer 2002 events, we used temperature records from 7 and $11 \mathrm{~m}$ depth for the first case and 7 and $14 \mathrm{~m}$ for the second one.
The net surface heat flux was estimated using the bulk equation provided by Gill (1982), and by using available data on visible radiation (PAR), wind, humidity, and air temperature from the meteorological station located at Las Cruces. Atmospheric pressure data from $33^{\circ} \mathrm{S}, 74^{\circ} \mathrm{W}$ was obtained from PFEL, and we assumed cloudless skies for all calculations (Gill 1982, Kaplan et al. 2003). Visible radiation was transformed to incoming radiation by supposing that visible radiation represenst a constant fraction of 0.4 of total incoming radiation (Gill 1982, Kaplan et al. 2003). Total energy input was dominated by solar radiation, with sensible and latent heat fluxes being of secondary importance. We conducted these estimates for all large warming events and selected a few periods of small temperature increases (Table 1). Although quantitative results from these calculations should be interpreted with caution due to approximation in parameter estimates, qualitative results are robust and allowed us to contrast different situations.
Editorial responsibility: Otto Kinne (Editor-in-Chief), Oldendorf/Luhe, Germany
Submitted: October 19, 2004; Accepted: September 2, 2005 Proofs received from author(s): February 8, 2006 